\title{
Metabotropic Regulation of Intrinsic Excitability by Synaptic Activation of Kainate Receptors
}

\author{
Zare Melyan, ${ }^{1}$ Barrie Lancaster, ${ }^{2}$ and Howard V. Wheal ${ }^{1}$ \\ ${ }^{1}$ Neuroscience Group, School of Biological Sciences, University of Southampton, Southampton S016 7PX, United Kingdom, and ${ }^{2}$ Wolfson Institute for \\ Biomedical Research, University College London, London WC1E 6BT, United Kingdom
}

\begin{abstract}
Prolonged modification of intrinsic neuronal excitability is gaining prominence as an activity-dependent form of plasticity. Here we describe a potential synaptic initiation mechanism for these changes in which release of the transmitter glutamate acts on kainate receptors to regulate the postspike slow afterhyperpolarization (sAHP). This action of synaptically released glutamate was occluded by previous kainate application. Furthermore, inhibition of glutamate uptake enhanced the effects of synaptic activation. Glutamatemediated kainate receptor inhibition of sAHP current $\left(I_{\mathrm{sAHP}}\right)$ was blocked by the PKC inhibitor calphostin C, confirming the requirement for a metabotropic signaling cascade. These data describe a new physiological function for glutamate release: activation of metabotropic kainate receptors, which control directly the excitability of pyramidal cells and probably contribute to prolonged excitability changes.
\end{abstract}

Key words: calphostin C; hippocampus; kainic acid; potassium channels; protein kinase C; pyramidal cells; kainate receptor

\section{Introduction}

Kainate receptors (KARs) in the hippocampus have direct actions on intrinsic cell excitability and influence transmitter release. The latter include regulating GABA release, evoked GABA responses, or interneuron activity (Fisher and Alger, 1984; Clarke et al., 1997; Rodriguez-Moreno et al., 1997; Cossart et al., 1998; Min et al., 1999; Semyanov and Kullmann, 2001). Additionally, glutamate release at CA1 pyramidal cell synapses is depressed (Chittajallu et al., 1996; Kamiya and Ozawa, 1998; Vignes et al., 1998; Frerking et al., 2001), and biphasic properties have been detected on glutamate release at mossy fiber synapses onto CA3 pyramidal cells (Vignes et al., 1998; Kamiya and Ozawa, 2000; Schmitz et al., 2000, 2001a,b). Kainate application can alter the network properties of hippocampal synaptic circuitry by promoting oscillations (Buhl et al., 1998) and seizure-like activity (Robinson and Deadwyler, 1981; Ashwood et al., 1986; Gho et al., 1986). However, our understanding of the physiological function of KARs, particularly with regard to their metabotropic properties, is still being refined (Lerma, 2003).

Pertussis toxin-sensitive G-proteins and protein kinase C (PKC) are required for kainate action on GABA release (Rodriguez-Moreno and Lerma, 1998). Pertussis toxin and NEM ( $N$-ethylmaleimide, an inhibitor of pertussis toxin-sensitive G-proteins) also block the KAR-mediated depression of glutamate release at CA1 pyramidal cell synapses (Frerking et al., 2001); however, protein kinase inhibitors are without effect on this release process. These presynaptic effects of kainate on GABA

Received Dec. 4, 2003; revised March 17, 2004; accepted March 24, 2004.

We thank Dr. M. Cuttle for his technical assistance and The Wellcome Trust, Sir Jules Thorn Charitable Trust, and the Royal Society for their support.

Correspondence should be addressed to H. V. Wheal, School of Biological Sciences, University of Southampton, Bassett Crescent East, Southampton Hants S016 7PX, UK. E-mail: wheal@soton.ac.uk.

DOI:10.1523/JNEUROSCI.5356-03.2004

Copyright $\odot 2004$ Society for Neuroscience $\quad$ 0270-6474/04/244530-05\$15.00/0 and glutamate release can be reproduced by glutamate released from excitatory synapses (Min et al., 1999; Schmitz et al., 2000).

Despite this evidence that KARs engage presynaptic mechanisms controlling transmitter release onto CA1 pyramidal cells, no KAR-mediated component to postsynaptic responses has been found in this region (Frerking et al., 2001). We recently described a novel metabotropic role for KARs in controlling the excitability of CA1 pyramidal cells via modulation of a slow afterhyperpolarization (sAHP $/ I_{\text {sAHP }}$ ) (Melyan et al., 2002). Similar to actions of kainate on GABA release from interneurons (Rodriguez-Moreno and Lerma, 1998), kainate modulation of the $I_{\mathrm{sAHP}}$ was prevented by inhibitors of metabotropic signaling cascades, including NEM and the PKC inhibitor calphostin C (Melyan et al., 2002).

Here we ascribe a new physiological function to this metabotropic kainate receptor (mKAR) in which glutamate released from excitatory afferents in area CA1 of the hippocampus mimics the action of kainate on these receptors. This was an activitydependent process and was potentiated in the presence of the glutamate uptake blocker DL-threo- $\beta$-benzyloxyaspartate (TBOA) (Arnth-Jensen et al., 2002). The actions of released glutamate were occluded by previous activation of the KARs. Glutamate-induced kainate receptor inhibition of the $I_{\mathrm{sAHP}}$ was long-lasting and also was blocked by the PKC inhibitor calphostin $\mathrm{C}$, confirming the role of a metabotropic signaling cascade.

\section{Materials and Methods}

Hippocampi were obtained from 14- to 19-d-old rats after decapitation. Transverse slices $(400 \mu \mathrm{m})$ were cut with a Vibratome and incubated in an interface chamber at room temperature before transfer to a submerged recording chamber. The storage and perfusion solution contained (in mM): $119 \mathrm{NaCl}, 2.5 \mathrm{KCl}, 1.3 \mathrm{MgSO}_{4}, 2.5 \mathrm{CaCl}_{2}, 1 \mathrm{NaH}_{2} \mathrm{PO}_{4}, 26$ $\mathrm{NaHCO}_{3}$, and 11 glucose and was gassed with $95 \% \mathrm{O}_{2} / 5 \% \mathrm{CO}_{2}$. Recordings were made at $28-30^{\circ} \mathrm{C}$ with recording pipettes containing (in mM): 150 potassium methylsulfate, $10 \mathrm{KCl}, 10 \mathrm{HEPES}, 4 \mathrm{NaCl}, 4 \mathrm{Mg}_{2} \mathrm{ATP}$, and 
$0.4 \mathrm{Na}_{4} \mathrm{GTP}$. Osmolarity was adjusted to $280-290 \mathrm{mOsm} / \mathrm{l}$ and $\mathrm{pH}$ to 7.35-7.4 with $\mathrm{KOH}$. The methylsulfate anion was used because it has been shown to preserve $I_{\mathrm{sAHP}}$ in a form similar to that observed with sharp electrode recordings (Lancaster and Adams, 1986; Zhang et al., 1994). Chemicals were purchased from Sigma (Poole, UK), with the following exceptions: kainic acid (Ocean Produce International, Shelburne, Nova Scotia, or Sigma), NaCl (Fisher Scientific, Loughborough, Leicestershire, UK), potassium methylsulfate (ICN Biomedicals, Irvine, CA), calphostin C (Calbiochem, La Jolla, CA). CNQX, DL-AP5, (S)MCPG, MSOP, 2-OH-saclofen, DPCPX, AM 251, and naloxone were obtained from Tocris Cookson (Bristol, UK).

Whole-cell patch-clamp recordings were made from stratum pyramidale without visual identification. Open pipette resistance was $2-4 \mathrm{M} \Omega$, and access resistance during recordings was $<20 \mathrm{M} \Omega$; series resistance compensation was not used. $I_{\text {sAHP }}$ was recorded (Axopatch $200 \mathrm{~B}$ or $1 \mathrm{D}$ amplifier, Axon Instruments, Union City, CA) in neurons voltageclamped at holding potentials from -50 to $-65 \mathrm{mV}$ after $80 \mathrm{msec}$ voltage steps to $-10 \mathrm{mV}$ applied every $20 \mathrm{sec}$. The records were filtered at $1 \mathrm{kHz}$ and sampled at $2 \mathrm{kHz}$. KAR responses were isolated by using an antagonist mixture that contained $100 \mu \mathrm{M}$ APV to block NMDAR, $100 \mu \mathrm{M}$ GYKI52466 or 50-100 $\mu \mathrm{M}$ GYKI53655 to block AMPAR, 1 mM MCPG and $250 \mu \mathrm{M}$ MSOP to block mGluRs, $100 \mu \mathrm{M}$ picrotoxin to block $\mathrm{GABA}_{\mathrm{A}} \mathrm{R}, 200 \mu \mathrm{M}$ 2-OH-saclofen to block $\mathrm{GABA}_{\mathrm{B}} \mathrm{R}, 1 \mu \mathrm{M}$ atropine sulfate to block muscarinic AChR, $10 \mu \mathrm{M}$ naloxone to block opioid receptors, $2 \mu \mathrm{M}$ AM 251 to block cannabinoid $\mathrm{CB}_{1}$ receptors, and $0.1 \mu \mathrm{M}$ DPCPX to block adenosine receptors. A stimulating electrode was positioned in stratum radiatum to recruit Schaffer collaterals and commissural fibers. The effect of synaptically released glutamate was assessed by comparing slow AHP currents induced before and after a train of five stimuli at $100 \mathrm{~Hz}$ delivered via the stimulating electrode (Heuss et al., 1999). Measurement of sAHP amplitude was made at the peak or plateau region of the response that occurred 300-400 msec after the depolarization. The average values of inhibition provided in the text are from $5 \mathrm{~min}$ epochs commencing $10 \mathrm{~min}$ after the manipulation ( $5 \mathrm{~min}$ after the multiple manipulations in Fig. 3). Data are given as the means \pm SEM, and the significance was assessed with ANOVA.

\section{Results}

We first tested whether synaptic activation of KARs can evoke an inhibition of $I_{\mathrm{sAHP}}$ similar to that produced by kainate (Fig. 1). A pharmacological isolation of kainate receptors was created by a mixture of blockers used in all of the experiments (see Materials and Methods) (Melyan et al., 2002). In the presence of this mixture the sequence of EPSC and IPSC responses to single-pulse synaptic stimulation was abolished (Fig. $1 B$ ). So that kainate receptors in CA1 pyramidal cells could be activated in this mixture, a train of five pulses at $100 \mathrm{~Hz}$ was used (Min et al., 1999). It is known that kainate receptors on CA1 pyramidal cells do not contribute to EPSCs (for review, see Frerking and Nicoll, 2000). Accordingly, in the presence of the antagonists the release of glutamate by the 5 pulse, $100 \mathrm{~Hz}$ stimulation did not produce any ionotropic response (Fig. $1 B$ ).

Figure $1 C$ shows that the short train of glutamate release resulted in a long-lasting inhibition of the peak amplitude of slow AHP current $(37 \pm 1 \%$, mean \pm SEM; $n=8)$. This is similar to the reported action of $200 \mathrm{~nm}$ kainate $(34 \pm 6 \%$; Melyan et al., 2002). $I_{\text {sAHP }}$ inhibition was not accompanied by significant changes in holding current. The summary time course of $I_{\text {sAHP }}$ inhibition from eight experiments is shown in Figure $1 D$. For comparison, the data of Figure $1 E$ illustrate the stability of $I_{\text {sAHP }}$ over a similar time course in the absence of a train of stimuli.

When synaptic activation was performed in the presence of the glutamate uptake inhibitor TBOA $(50-100 \mu \mathrm{M})$, there was a modest but significant increase in $I_{\text {sAHP }}$ inhibition to $45 \pm 2 \%$ at 15 min after stimulation ( $p<0.001$; two-way ANOVA). Figure $2 \mathrm{~A}$ shows the summary time course of $I_{\text {sAHP }}$ inhibition produced
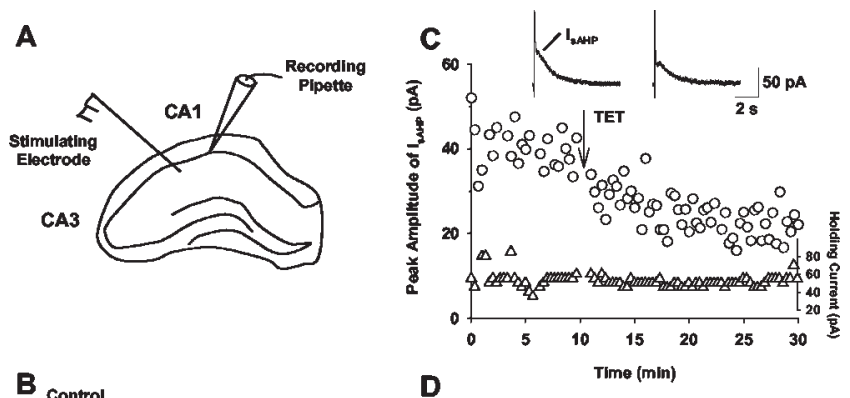

B Control
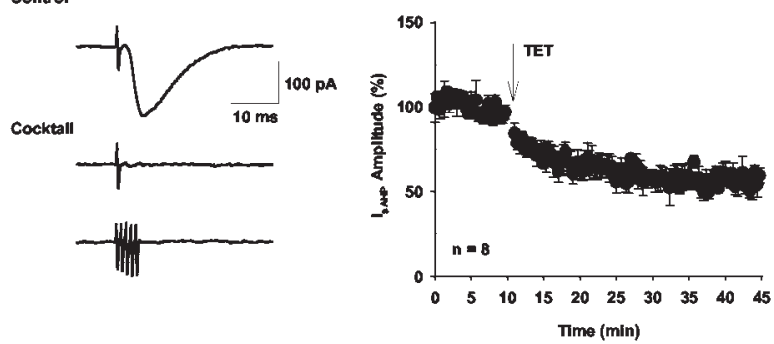

E

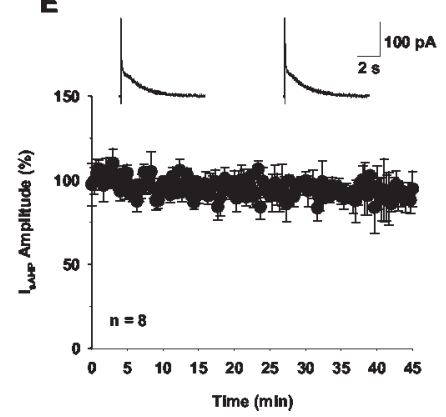

Figure 1. Synaptically released glutamate inhibits $I_{\text {sAHP }}$ currents in CA1 pyramidal cells. $A$, Schematic illustration of the hippocampal slice showing the positioning of the electrodes. $B$, Single-pulse stimulation of Schaffer/commissural afferents evoked an EPSC in a CA1 pyramidal cell that was blocked by the antagonist mixture. A 5 pulse, $100 \mathrm{~Hz}$ stimulation also did not produce any synaptic response in the presence of the mixture. C, A 5 pulse, $100 \mathrm{~Hz}$ stimulation reduced the amplitude of $I_{\text {SAHP. }}$. The peak amplitudes of $I_{\text {SAHP }}$ (circles) and the holding current values (triangles) were plotted against time. Sample traces were obtained before and $15 \mathrm{~min}$ after a train of stimuli. $D$, Summary time course of $I_{\text {SAHP }}$ inhibition from eight experiments (mean \pm SEM). E, Summary time course for $I_{\text {SAHP }}$ amplitude without the application of trains of synaptic stimuli $(n=8)$.

by 5 pulse, $100 \mathrm{~Hz}$ stimulation in the presence of TBOA $(n=8)$. To test whether the effect of synaptically released glutamate on $I_{\text {sAHP }}$ was mediated by kainate receptors, we applied the nonNMDA ionotropic glutamate receptor blocker CNQX. The summary data of seven experiments are shown in Figure $2 B$. Previous application of $20 \mu \mathrm{M}$ CNQX completely abolished the effect of synaptic stimulation on $I_{\mathrm{sAHP}}$, even in the presence of TBOA. This indicates that kainate receptors account fully for the actions of released glutamate after uptake block.

Increasing the number of stimuli in the train up to 20 also increased the inhibition of slow AHP currents. Individual stimuli were insufficient to inhibit $I_{\text {sAHP }}(4 \pm 4 \% ; n=7)$. Inhibition produced by five stimuli $(37 \pm 1 \%)$ was not significantly different from that produced by 10 pulses ( $38 \pm 2 \% ; n=7)$, although a further increase in activity to 20 pulses produced an inhibition of $63 \% \pm 1.5 \%(n=8)$.

To test whether synaptic stimulation and bath-applied kainate act on the same population of kainate receptors to inhibit $I_{\text {sAHP, }}$, we investigated whether synaptically induced inhibition can be occluded by the previous application of kainate. The data presented in Figure $3 B$ show that a 200 nm kainate application pro- 

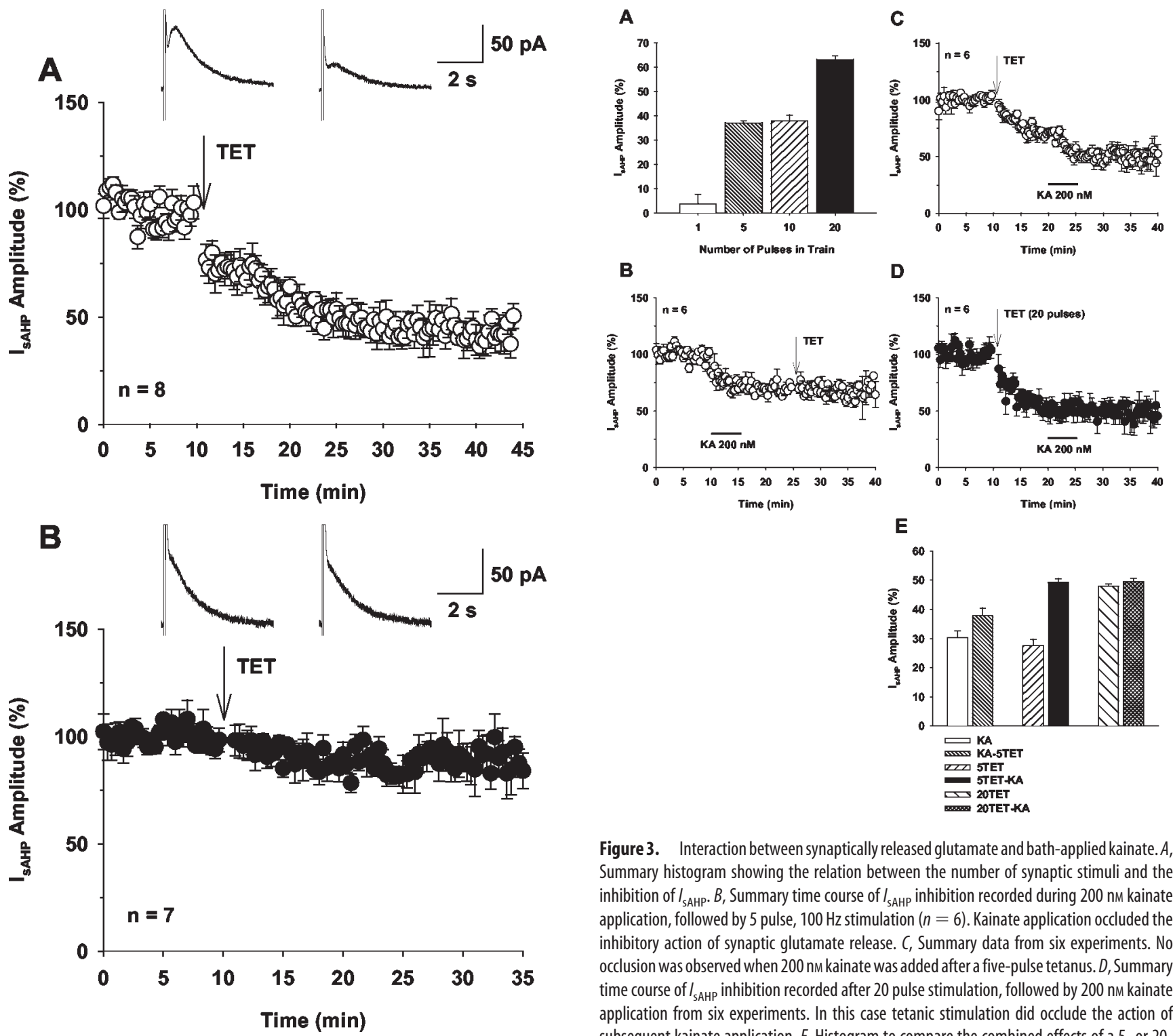

Figure 3. Interaction between synaptically released glutamate and bath-applied kainate. $A$, Summary histogram showing the relation between the number of synaptic stimuli and the inhibition of $I_{\text {sAHP. }} . B$, Summary time course of $I_{\text {SAHP }}$ inhibition recorded during $200 \mathrm{~nm}$ kainate application, followed by 5 pulse, $100 \mathrm{~Hz}$ stimulation $(n=6)$. Kainate application occluded the inhibitory action of synaptic glutamate release. C, Summary data from six experiments. № occlusion was observed when $200 \mathrm{~nm}$ kainate was added after a five-pulse tetanus. D, Summary time course of $I_{\text {SAHP }}$ inhibition recorded after 20 pulse stimulation, followed by $200 \mathrm{~nm}$ kainate application from six experiments. In this case tetanic stimulation did occlude the action of subsequent kainate application. $E$, Histogram to compare the combined effects of a 5- or 20pulse train in combination with kainate application. All panels show mean \pm SEM.

Figure 2. $I_{\text {sAHP }}$ inhibition is mediated by glutamate acting on kainate receptors. A, Block of glutamate uptake increased the effect of tetanic stimulation. Sample traces were obtained before and after a tetanus in the same neuron in the presence of the glutamate uptake inhibitor TBOA (50 $\mu \mathrm{m}$; averages of 15 trials). Summary time course of $I_{\text {sAHP }}$ inhibition recorded in the presence of TBOA from eight experiments (mean \pm SEM) is shown in the graph. $B$, Previous application of the AMPA/kainate receptor antagonist CNQX completely abolished the effect of synaptically released glutamate in the presence of TBOA. Sample traces were obtained in the presence of $20 \mu \mathrm{M} C N Q X$ and TBOA before and after a tetanic stimulation in the same neuron (averages of 15 trials). Summary time course of $I_{\text {sAHP }}$ amplitude recorded in the presence of 20 $\mu \mathrm{M}$ CNQX from seven experiments (mean $\pm \mathrm{SEM}$ ) is plotted in the graph.

duced $30 \pm 2 \%$ inhibition of $I_{\mathrm{sAHP}}$. A subsequent five-pulse train to activate the excitatory synapses produced further inhibition of only $7 \pm 2 \%(n=6)$ (Fig. 3E). When five stimuli at $100 \mathrm{~Hz}$ preceded kainate application, occlusion was not observed (Fig. $3 C, E)$. Synaptic stimulation evoked $28 \pm 2 \%$ inhibition compared with the kainate effect of $22 \pm 2 \%$ inhibition $(n=6)$ that followed; this is, however, less inhibition than expected for naive cells (30-34\%) (Melyan et al., 2002; this work). This difference could result from some depression of glutamate release when a stimulus train is applied in the presence of kainate. Alternatively, the agonist could be acting on different fractions of the KAR population in the two procedures. If glutamate release acts on a

smaller fraction of the KARs than bath-applied kainate, this would account for occlusion observed only when the kainate application preceded glutamate release. Indeed, when we increased the number of stimuli in the train from 5 to 20 , greater inhibition of $I_{\mathrm{sAHP}}$ was observed $(48 \pm 1 \% ; n=6)$ and the action of bath-applied kainate was then indistinguishable $(2 \pm 1 \%$ inhibition) (Fig. $3 D, E$ ). Thus, a sufficiently large glutamate release was able to occlude the action of kainate.

The modulation of $I_{\mathrm{sAHP}}$ by synaptically released glutamate is apparent without any accompanying changes in membrane conductance. This implies that the ionotropic properties of the KAR are insufficient to account for these effects on $I_{\mathrm{sAHP}}$. By analogy with the effects of exogenous kainate, we tested for metabotropic actions by using the PKC inhibitor calphostin C. Preincubation of slices with $1 \mu \mathrm{M}$ calphostin C for $2-4 \mathrm{hr}$ prevented $I_{\mathrm{sAHP}}$ inhibition after brief activity of excitatory afferents $(n=8)$ (Fig. 4). The histogram in Figure $4 B$ shows that kainate had a little effect on $I_{\mathrm{sAHP}}$ in calphostin C-treated slices $(6 \pm 2 \%)$ compared with control slices $(34 \pm 1 \%)$. 

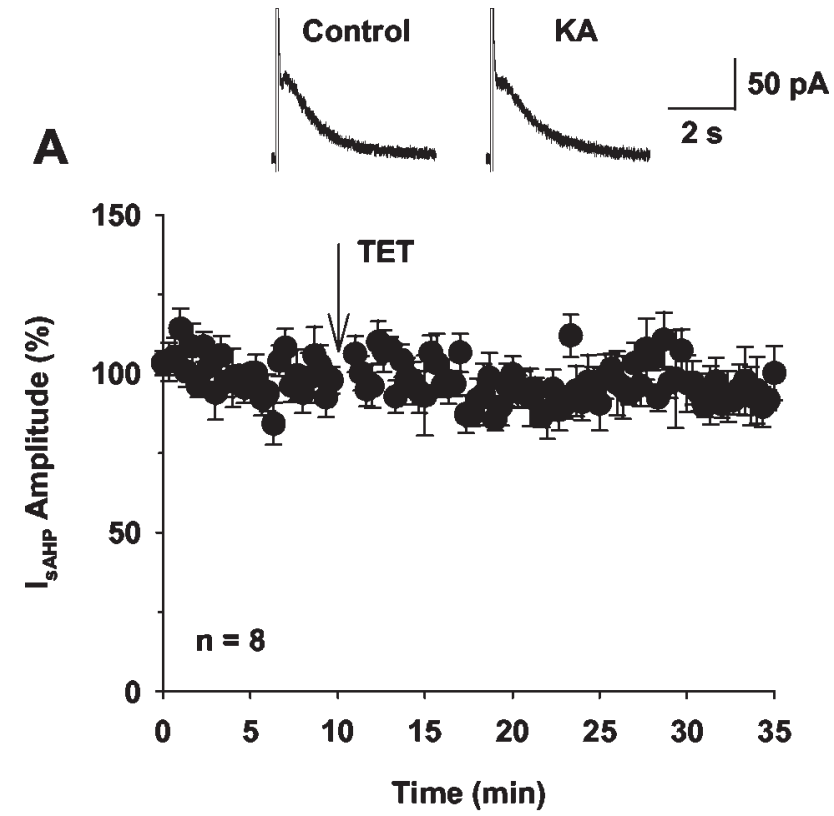

B

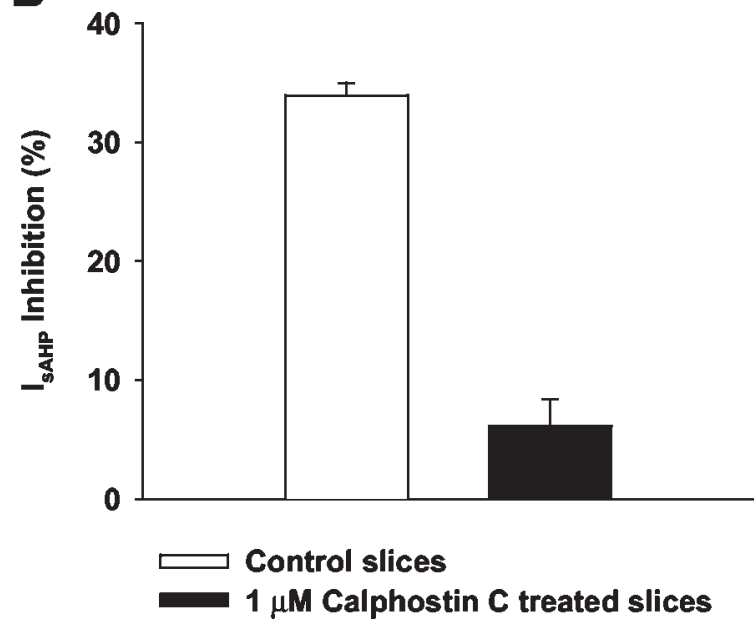

Figure 4. $I_{\text {SAHP }}$ inhibition produced by the activation of kainate receptors involves a metabotropic function. $A$, Sample traces (averages of 15 trials) were recorded in calphostin C-treated slices before and after tetanic stimulation. Summary time course of $I_{\text {sAHP }}$ inhibition from eight experiments (mean $\pm \mathrm{SEM}$ ) is presented in the graph. $B$, The histogram shows the average percentage inhibition (mean \pm SEM) of $l_{\text {sAHP. }}$ A train of five stimuli inhibited $l_{\text {sAHP }}$ in control slices (white bar). In calphostin C-treated slices (1 $\mu \mathrm{m}$; black bar) kainate-induced inhibition was reduced significantly.

\section{Discussion}

Together, these data show that synaptically released glutamate inhibits $I_{\text {sAHP }}$ acting via the metabotropic property of kainate receptors on CA1 pyramidal cells. The participation of glutamate released from excitatory afferents in this physiological role was confirmed by the application of the glutamate uptake blocker TBOA (50-100 $\mu \mathrm{M})$ (Arnth-Jensen et al., 2002), which increased the inhibition of the $I_{\text {sAHP }}$ by trains of stimuli. The inhibition of the $I_{\text {sAHP }}$ by glutamate was activity-dependent in that increasing the number of pulses in the train from 5 to 20 also increased inhibition of the $I_{\text {sAHP }}$ from 37 to $63 \%$. Glutamate released by 20 pulses also occluded the application of kainate $(200 \mathrm{nM})$, and both actions were blocked by the application of CNQX, confirming the involvement of KARs.

No inward currents were generated by the glutamate released by trains of pulses, and a requirement for $\mathrm{PKC}$ was confirmed by the sensitivity of the inhibition to calphostin $\mathrm{C}$. The time course of inhibition of the $I_{\mathrm{sAHP}}$ is consistent with the previous report involving low kainate concentrations (Melyan et al., 2002). Interestingly, neither the inhibition of the $I_{\text {sAHP }}$ by synaptic release nor bath-applied kainate showed significant recovery. This suggests that the prolonged nature of the effects is not attributable to prolonged agonist exposure but might reflect the characteristics of the transduction mechanism.

Prolonged changes in neuronal excitability can result from modulation of intrinsic conductances. This has been reported for brain regions involved in motor learning (Nelson et al., 2003) and for the hippocampus in which an extensive literature has documented changes in the slow AHP associated with learning (Disterhoft et al., 1986; Moyer et al., 1996; Giese et al., 1998; Saar et al., 2001) The sAHP is a well established mechanism for controlling repetitive firing of action potentials (Madison and Nicoll, 1984) or burst firing patterns during hyperexcitability (Traub et al., 1993). Furthermore, the sAHP is sensitive to modulation by a wide variety of transmitters when applied to brain slice preparations (Vogalis et al., 2003). Despite this, it is rare to demonstrate modulation of the sAHP that follows intrinsic neurotransmitter release. The neurohumoral action of released acetylcholine on muscarinic receptors was first to be shown to inhibit the sAHP (Cole and Nicoll, 1983). Single mossy fiber stimulation has been mentioned to act via mGluRs to inhibit $I_{\text {sAHP }}$ in CA3 neurons (Heuss et al., 1999). Our data characterize a further, potent metabotropic action of synaptically released glutamate in the hippocampus. This action leads to prolonged changes of intrinsic excitability and could play a key role in the generation of epileptiform seizure-like activity (Robinson and Deadwyler, 1981; Ashwood et al., 1986; Gho et al., 1986).

There is no working hypothesis for the link between KARs and a second messenger cascade. In fact, details of the KAR subunit composition are still incomplete. In the hippocampus GluR5 subunits are expressed principally in interneurons where they are involved in controlling the release of GABA (Clarke et al., 1997; Rodriguez-Moreno et al., 1997; Cossart et al., 1998; Bureau et al., 1999; Lerma et al., 2001; Semyanov and Kullmann, 2001) (but see Mulle et al., 2000). CA1 and CA3 pyramidal cells contain GluR6 together with KA1 and KA2 subunits of GABA (Bureau et al., 1999; Lerma et al., 2001). When exogenous kainate was used to assess the pharmacological profile of the metabotropic function of KARs in CA1 neurons, the results were consistent with participation of GluR6 subunits (Melyan et al., 2002). We predict that GluR6 subunits are required for these synaptic actions of glutamate; however, further experiments using GluR6 ${ }^{-1-}$ (Bureau et al., 1999) would be required to test this possibility. At a network level these metabotropic receptors well may contribute to the generation and spread of seizure-like activity. It is, therefore, interesting that mice devoid of GluR6 subunits are less susceptible to seizures, confirming a role for GluR6-containing KARs in modulating hippocampal network excitability (Mulle et al., 1998). The results here suggest a possible contributory explanation for seizure resistance in these animals.

\section{References}

Arnth-Jensen N, Jabaudon D, Scanziani M (2002) Cooperation between independent hippocampal synapses is controlled by glutamate uptake. Nat Neurosci 5:325-331.

Ashwood TJ, Lancaster B, Wheal HV (1986) Intracellular electrophysiology of CA1 pyramidal neurones in slices of the kainic acid lesioned hippocampus of the rat. Exp Brain Res 62:189-198. 
Buhl EH, Tamas G, Fisahn A (1998) Cholinergic activation and tonic excitation induce persistent gamma oscillations in mouse somatosensory cortex in vitro. J Physiol (Lond) 513(Pt 1):117-126.

Bureau I, Bischoff S, Heinemann SF, Mulle C (1999) Kainate receptormediated responses in the CA1 field of wild-type and GluR6-deficient mice. J Neurosci 19:653-663.

Chittajallu R, Vignes M, Dev KK, Barnes JM, Collingridge GL, Henley JM (1996) Regulation of glutamate release by presynaptic kainate receptors in the hippocampus. Nature 379:78-81.

Clarke VR, Ballyk BA, Hoo KH, Mandelzys A, Pellizzari A, Bath CP, Thomas J, Sharpe EF, Davies CH, Ornstein PL, Schoepp DD, Kamboj RK, Collingridge GL, Lodge D, Bleakman D (1997) A hippocampal GluR5 kainate receptor regulating inhibitory synaptic transmission. Nature 389:599-603.

Cole AE, Nicoll RA (1983) Acetylcholine mediates a slow synaptic potential in hippocampal pyramidal cells. Science 221:1299-1301.

Cossart R, Esclapez M, Hirsch JC, Bernard C, Ben Ari Y (1998) GluR5 kainate receptor activation in interneurons increases tonic inhibition of pyramidal cells. Nat Neurosci 1:470-478.

Disterhoft JF, Coulter DA, Alkon DL (1986) Conditioning-specific membrane changes of rabbit hippocampal neurons measured in vitro. Proc Natl Acad Sci USA 83:2733-2737.

Fisher RS, Alger BE (1984) Electrophysiological mechanisms of kainic acidinduced epileptiform activity in the rat hippocampal slice. J Neurosci 4:1312-1323.

Frerking M, Nicoll RA (2000) Synaptic kainate receptors. Curr Opin Neurobiol 10:342-351.

Frerking M, Schmitz D, Zhou Q, Johansen J, Nicoll RA (2001) Kainate receptors depress excitatory synaptic transmission at CA3 $\rightarrow$ CA1 synapses in the hippocampus via a direct presynaptic action. J Neurosci 21:2958-2966.

Gho M, King AE, Ben Ari Y, Cherubini E (1986) Kainate reduces two voltage-dependent potassium conductances in rat hippocampal neurons in vitro. Brain Res 385:411-414.

Giese KP, Storm JF, Reuter D, Fedorov NB, Shao L-R, Leicher T, Pongs O, Silva AJ (1998) Reduced $\mathrm{K}^{+}$channel inactivation, spike broadening, and after-hyperpolarization in $\mathrm{Kv} \beta 1.1$-deficient mice with impaired learning. Learn Mem 5:257-273.

Heuss C, Scanziani M, Gahwiler BH, Gerber U (1999) G-proteinindependent signaling mediated by metabotropic glutamate receptors. Nat Neurosci 2:1070-1077.

Kamiya H, Ozawa S (1998) Kainate receptor-mediated inhibition of presynaptic $\mathrm{Ca}^{2+}$ influx and EPSP in area CAl of the rat hippocampus. J Physiol (Lond) 509(Pt 3):833-845.

Kamiya H, Ozawa S (2000) Kainate receptor-mediated presynaptic inhibition at the mouse hippocampal mossy fibre synapse. J Physiol (Lond) 523(Pt 3):653-665.

Lancaster B, Adams PR (1986) Calcium-dependent current generating the afterhyperpolarization of hippocampal neurons. J Neurophysiol 55:1268-1282.

Lerma J (2003) Roles and rules of kainate receptors in synaptic transmission. Nat Rev Neurosci 4:481-495.

Lerma J, Paternain AV, Rodriguez-Moreno A, Lopez-Garcia JC (2001) Molecular physiology of kainate receptors. Physiol Rev 81:971-998.
Madison DV, Nicoll RA (1984) Control of the repetitive discharge of rat CA 1 pyramidal neurones in vitro. J Physiol (Lond) 354:319-331.

Melyan Z, Wheal HV, Lancaster B (2002) Metabotropic-mediated kainate receptor regulation of $\mathrm{I}_{\mathrm{sAHP}}$ and excitability in pyramidal cells. Neuron 34:107-114.

Min MY, Melyan Z, Kullmann DM (1999) Synaptically released glutamate reduces gamma-aminobutyric acid (GABA)ergic inhibition in the hippocampus via kainate receptors. Proc Natl Acad Sci USA 96:9932-9937.

Moyer Jr JR, Thompson LT, Disterhoft JF (1996) Trace eyeblink conditioning increases CA1 excitability in a transient and learning-specific manner. J Neurosci 16:5536-5546.

Mulle C, Sailer A, Perez-Otano I, Dickinson-Anson H, Castillo PE, Bureau I, Maron C, Gage FH, Mann JR, Bettler B, Heinemann SF (1998) Altered synaptic physiology and reduced susceptibility to kainate-induced seizures in GluR6-deficient mice. Nature 392:601-605.

Mulle C, Sailer A, Swanson GT, Brana C, O’Gorman S, Bettler B, Heinemann SF (2000) Subunit composition of kainate receptors in hippocampal interneurons. Neuron 28:475-484.

Nelson AB, Krispel CM, Sekirnjak C, du Lac S (2003) Long-lasting increases in intrinsic excitability triggered by inhibition. Neuron 40:609-620.

Robinson JH, Deadwyler SA (1981) Kainic acid produces depolarization of CA3 pyramidal cells in the vitro hippocampal slice. Brain Res 221:117-127.

Rodriguez-Moreno A, Lerma J (1998) Kainate receptor modulation of GABA release involves a metabotropic function. Neuron 20:1211-1218.

Rodriguez-Moreno A, Herreras O, Lerma J (1997) Kainate receptors presynaptically downregulate GABAergic inhibition in the rat hippocampus. Neuron 19:893-901.

Saar D, Grossman Y, Barkai E (2001) Long-lasting cholinergic modulation underlies rule learning in rats. J Neurosci 21:1385-1392.

Schmitz D, Frerking M, Nicoll RA (2000) Synaptic activation of presynaptic kainate receptors on hippocampal mossy fiber synapses. Neuron 27:327-338.

Schmitz D, Mellor J, Nicoll RA (2001a) Presynaptic kainate receptor mediation of frequency facilitation at hippocampal mossy fiber synapses. Science 291:1972-1976.

Schmitz D, Mellor J, Frerking M, Nicoll RA (2001b) Presynaptic kainate receptors at hippocampal mossy fiber synapses. Proc Natl Acad Sci USA 98:11003-11008.

Semyanov A, Kullmann DM (2001) Kainate receptor-dependent axonal depolarization and action potential initiation in interneurons. Nat Neurosci 4:718-723.

Traub RD, Miles R, Jefferys JG (1993) Synaptic and intrinsic conductances shape picrotoxin-induced synchronized after-discharges in the guineapig hippocampal slice. J Physiol (Lond) 461:525-547.

Vignes M, Clarke VR, Parry MJ, Bleakman D, Lodge D, Ornstein PL, Collingridge GL (1998) The GluR5 subtype of kainate receptor regulates excitatory synaptic transmission in areas CA1 and CA3 of the rat hippocampus. Neuropharmacology 37:1269-1277.

Vogalis F, Storm JF, Lancaster B (2003) SK channels and the varieties of slow afterhyperpolarizations in neurons. Eur J Neurosci 18:3155-3166.

Zhang L, Weiner JL, Valiante TA, Velumian AA, Watson PL, Jahromi SS, Schertzer S, Pennefather P, Carlen PL (1994) Whole-cell recording of the $\mathrm{Ca}^{2+}$-dependent slow afterhyperpolarization in hippocampal neurones: effects of internally applied anions. Pflugers Arch 426:247-253. 